\title{
Socialization of Terms of Use and Privacy Policy on Indonesian e-commerce Websites
}

\author{
Aloysius Bernanda Gunawan ${ }^{1^{*}}$, Anindito ${ }^{2}$, Rido Sarwono ${ }^{2}$ \\ Bambang Pratama ${ }^{3}$ \\ ${ }^{I}$ Communication Study Program, Faculty of Economic and Communication, Bina Nusantara University, Jakarta, 11530, Indonesia \\ ${ }^{2}$ Information System Department, School of Information System, Bina Nusantara University, Jakarta, 11530, Indonesia \\ ${ }^{3}$ Law Study Program, Faculty of Humanities, Bina Nusantara University, Jakarta, 11530, Indonesia
}

\section{ARTICLE INFO}

AIJ use only:

Received date : 05 May 2020

Revised date : 20 May 2020

Accepted date : 05 July 2020

\section{Keywords:}

online privacy

e-commerce

term of use

\begin{abstract}
A B S T R A C T
This article aims to identify common practices in Indonesian ecommerce regarding terms of use and privacy policies. Website visit rankings from Alexa and Similarweb were used to identify the 10 most commonly visited e-commerce sites in Indonesia. Then, placement, length, and content structure of the terms of service and privacy policies of these websites were compared. Findings suggest that the information provided by these documents is sufficient and legally compliant, although some of the websites appear to disregard their importance. The actual contents of these documents were not analyzed and are thus open for further study. The information provided in this article may give merchants intending to open ecommerce stores in Indonesia some insight into how the protection of consumers' personal data leads to better service. This paper also proposes a simple framework for assessing the extent to which an ecommerce website successfully ensures that consumers agree and consent to its terms of use without burdening them with lengthy and obscure legal documents.
\end{abstract}

\section{INTRODUCTION}

Indonesia is projected to become the third largest e-commerce market in Asia by 2020 (Harsono, 2016) . Both independent businesses and mass retailers are enjoying the growth of this market. Acknowledging this growth, the Indonesian government established the Electronic Information and Technology Law in 2008 to regulate it.

At the beginning of the decade, the growth of ecommerce was slow due to low public trust regarding transaction security. Most e-commerce sites found that although they provided various payment methods, the majority of transactions were

\footnotetext{
* Corresponding author.

E-mail address: ab.gunawan@binus.ac.id

Article with open access under license
}

done through payment by bank transfer. However, due to the recent explosion in the ownership of smart phones, this gradually began to change. Some customers actually shifted to buying daily requirements online to save time while also taking advantage of slightly lower online prices including promotions and discounts.

However, the increase in the number of ecommerce customers does not necessarily imply heightened internet literacy. While Internet fraud and crime rates related to e-commerce are difficult to obtain, news of such cases can become viral on social media. Consumers Union has identified several issues that customers must consider during browsing: (1) identity; (2) advertising and sponsorship; (3) customer service; (4) corrections; and (5) privacy (ConsumersUnion, 2016). 
Research has revealed that not many customers care about privacy on websites (Adams, 2003). However, when privacy information is displayed prominently on a website, it may increase a customer's willingness to buv from or trust that websi Journal of Social Science | Jsss.co.id 41

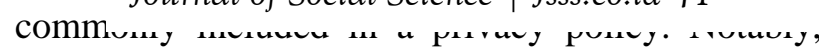
the absence of a privacy policy does not appear to discourage customers. The second piece of legal information is contained in the "terms of service," also called "terms of use" or "disclaimer." This information commonly conveys how a service provider expects a customer to use their website.

Although consumer education is important in Indonesia, delivery channels are limited. According to the 2013 Curriculum, the former minister of education deleted ICT as a special subject, reflecting the opinion that consumer education is best obtained through the market itself. This research analyzes privacy policies and terms of use on Indonesian e-commerce websites with the goal of identifying the best practices available for Indonesian e-commerce websites and improving our understanding of how we can educate and motivate consumers to follow recommended protective measures (Tsai, Egelman, Cranor, \& Acquisti, 2011).

\section{THEORY}

\section{Online Privacy}

Online privacy is the aspect of personal privacy that is related to communication over the Internet. It centers around the matter of obtaining, using, disclosing, and displaying personal data such as name, age, or behavior on a website. The concept of privacy involves space, decision, and information. In terms of space, individuals expect that their online rights will not be trespassed by others. In terms of decision, every individual expects to be able to determine the extent of personal space required. Some may freely disclose their birth date, for example, while others may not. In terms of information, privacy is meant to safeguard against the collection of information from various sources.

With the rise of the Internet in the 1990s and mobile networks in the 2000 s, online privacy has become a major concern. Most Internet users use commonly available tools to protect their basic privacy. However, some users prefer higher levels of privacy or even Internet anonymity. They may be particularly careful about what information they submit in online forms.
A competition for personal data access is ongoing between the corporation and the individual. Corporations pay to learn about and understand individual preferences to direct targeted advertising while some individuals work hard to divulge minimum personal data to avoid being harvested by corporations. Although the corporations' cause may be purely commercial, some parties use the same information for malicious acts such as spyware and malware. A major concern is Internet use by children and adolescents who do not particularly understand the risks involved in terms of their privacy.

Indonesia does not have a specific law regarding protection of personal data; rather, the relevant laws are scattered among various acts such as Law No. 7 of 1971 concerning Main Provisions of Archives, Law No. 8 of 1997 concerning Company Documents, Law No. 7 of 1992 concerning Banking as Amended by Law No. 10 of 1998, Law No. 36 of 2009 concerning Health, Law No. 36 of 1999 concerning Telecommunications and Law No. 23 of 2006 concerning Population Administration.

Law No. 11 of 2008 concerning Information and Electronic Transactions does not specifically regulate personal data but does contain some clauses that may be applied to cases of infringement. Article 26 of this Law regulates the use of personal data in electronic media only by consent of the owners. Illegal access to systems that may contain personal data is regulated in Article 30.

Government Regulations 82 of 2012, an implementing regulation for Law No. 11 of 2008, contains a minimal definition of personal data. Article 15 of the Act also regulates the responsibilities of providers to inform individuals in case of system failure, although no specific definition of failure is provided.

\section{Term of Use}

Terms of use, also known as terms of service, user agreements, or merely disclaimers, are commonly provided by content providers to regulate the use of their content by visiting users. A user is expected to abide by the set regulations when using the concerned website. Although various types of presentations are available, not all terms of use can be used effectively in court proceedings.

Three general types of terms of use exist. The first is clickwrap, in which the user must click a 
button to signify agreement with the terms. This type is almost always defensible in court due to the agreement made by the user; it complies with the mutual assent principle of agreements in Indonesian law. However, there is a loophole as persons who are of age and are capable have to consent to these agreements. This situation may be handled by inserting clauses that allow only persons of age to agree to the terms.

The second type is browsewrap, in which users do not have to click on anything. Rather, the service provider presumes that users automatically agree to their terms when they browse the relevant website. Such an agreement is not always admissible in court due to the mutual assent principle. A link to the terms or the terms themselves must be displayed prominently on the home page or navigation bar at the point where the user commonly enters the site for the terms to be admissible in court. A famous case is that of Zappos (Milne, Rohm, \& Bahl, 2004).

The third and last type includes all other methods of displaying terms of use, none of which are admissible in court due to their incompatibility with agreement terms in Indonesian Civil Code.

Terms of use are mostly critical in situations where in content use or misuse could be detrimental to the concerned service or to society in general. Since Act 11 of 2008, a content provider can be held responsible for the content hosted on their sites. This is dangerous especially for websites that display content provided by the users. It is not costeffective to monitor all submissions to the system. A common alternative to this is providing complaint centers where a visiting user may report a page or an entire site if it infringes their interests, that is, copyright. The service provider may then retract the content for a certain amount of time, thus allowing dispute resolution to proceed.

\section{Privacy Policies}

A privacy policy is defined as a legal statement that discloses to clients how a service provider collects, stores, releases, and uses their personal data. Although exact contents may vary in different jurisdictions according to applicable laws and regulations, various general guidelines have been created.

The Organization for Economic Cooperation and Development (OECD) held the Convention for the Protection of Individuals with regard to Automatic Processing of Personal Data (Convention 108) in 1981. This Convention provides guidelines for setting national regulations. Sweden, West Germany, France, and the United States created their own national laws in response. The OECD also issued the Recommendations of the Council Concerning Guidelines Governing the Protection of Privacy and Trans-Border Flows of Personal Data. The seven principles governing the recommendations were as follows:

- Notice-data subjects should be given notice when their data is being collected;

- Purpose-data should only be used for the purpose stated and not for any other purposes;

- Consent - data should not be disclosed without the data subject's consent;

- Security - collected data should be kept secure from any potential abuses;

- Disclosure-data subjects should be informed as to who is collecting their data;

- Access - data subjects should be allowed to access their data and make corrections to any inaccurate data; and

- Accountability - data subjects should have a method available to them to hold data collectors accountable for not following the above principles.

\section{METHOD \\ Data Collection}

We identified the top 10 ranked e-commerce websites in Indonesia from two free data providers, Alexa and SimilarWeb. The websites are listed in Table 1.

Table 1: Indonesian e-commerce Website Rankings in Alexa and SimilarWeb

\begin{tabular}{|c|c|c|l|}
\hline $\begin{array}{c}\text { Alexa } \\
\text { Rank }\end{array}$ & $\begin{array}{c}\text { SimilarWeb } \\
\text { Rank** }\end{array}$ & Website & Type \\
\hline 9 & 9 & tokopedia.com & marketplace \\
\hline 13 & 18 & bukalapak.com & marketplace \\
\hline 17 & 11 & lazada.co.id & $\begin{array}{l}\text { retail \& } \\
\text { marketplace }\end{array}$ \\
\hline 21 & 19 & elevenia.co.id & $\begin{array}{l}\text { retail \& } \\
\text { marketplace }\end{array}$ \\
\hline 43 & 23 & blibli.com & $\begin{array}{l}\text { retail \& } \\
\text { marketplace }\end{array}$ \\
\hline 62 & N/A*** & alfacart.com & $\begin{array}{l}\text { retail \& } \\
\text { marketplace }\end{array}$ \\
\hline 126 & N/A*** & blanja.com & $\begin{array}{l}\text { retail \& } \\
\text { marketplace }\end{array}$ \\
\hline 130 & N/A*** & shopee.co.id & $\begin{array}{l}\text { retail \& } \\
\text { marketplace }\end{array}$ \\
\hline 141 & N/A*** & bhinneka.com & retail \& \\
\hline
\end{tabular}




\begin{tabular}{|c|c|l|l|}
\hline 172 & N/A*** & mataharimall.com & $\begin{array}{l}\text { marketplace } \\
\text { marketplace }\end{array}$ \\
\hline
\end{tabular}

Data from Alexa was collected on November 14,

2016 from http://www.alexa.com/topsites/countries/ ID

** Data from SimilarWeb was collected on November 14, 2016 from https://www.similarweb.com/topwebsites/indonesia

*** SimilarWeb free access only provides data on the top 50 ranked sites.

\section{Data Analysis}

We obtained terms of use and privacy policy documents from these websites where applicable. If these documents were unavailable, we obtained similar documents having the same function.

We analyzed the texts contained in the obtained documents. Sections are categorized and compared with other documents of the same type.

\section{Summarization}

Results of the data analysis are discussed and summarized. The data are compared to common best practices to measure compliance. We discuss three points, namely, (1) document availability; (2) whether the links to the documents are prominently displayed; and (3) document length.

\section{RESULTS AND DISCUSSION Data Analysis}

We obtained the terms of use and privacy policies from the same websites listed in Table 1.These are listed in Table 2.

\begin{tabular}{|c|c|c|c|c|c|c|c|c|}
\hline No & Website & Location & $\begin{array}{l}\text { Show } \\
\text { notif }\end{array}$ & $\begin{array}{l}\text { Guest } \\
\text { buyer }\end{array}$ & $\begin{array}{c}\text { Terms } \\
\text { of } \\
\text { Use }\end{array}$ & $\begin{array}{c}\text { ToU } \\
\text { Length }\end{array}$ & $\begin{array}{l}\text { Privacy } \\
\text { Policy }\end{array}$ & $\begin{array}{c}\text { PP } \\
\text { Length }\end{array}$ \\
\hline 1 & tokopedia.com & $\begin{array}{l}\text { bottom- } \\
\text { middle }\end{array}$ & Yes & No & Yes & 5624 & Yes & 1421 \\
\hline 2 & bukalapak.com & $\begin{array}{l}\text { bottom- } \\
\text { middle }\end{array}$ & Yes & Yes & Yes & 2981 & Yes & 182 \\
\hline 3 & lazada.co.id & $\begin{array}{l}\text { bottom- } \\
\text { middle }\end{array}$ & No & Yes & Yes & 9642 & Yes & 1955 \\
\hline 4 & elevenia.co.id & $\begin{array}{l}\text { bottom- } \\
\text { middle }\end{array}$ & No & No & Yes & 4879 & ToU* & N/A \\
\hline 5 & blibli.com & $\begin{array}{l}\text { bottom- } \\
\text { middle }\end{array}$ & No & No & Yes & 3204 & Yes & 704 \\
\hline 6 & alfacart.com & $\begin{array}{c}\text { bottom- } \\
\text { left }\end{array}$ & No & No & Yes & 3614 & ToU* & N/A \\
\hline 7 & blanja.com & $\begin{array}{l}\text { bottom- } \\
\text { middle }\end{array}$ & No & No & Yes & 2838 & Yes & 2309 \\
\hline 8 & shopee.co.id & $\begin{array}{c}\text { bottom- } \\
\text { right }\end{array}$ & Yes & Yes & Yes & 7811 & Yes & 4876 \\
\hline 9 & bhinneka.com & $\begin{array}{l}\text { bottom- } \\
\text { middle }\end{array}$ & No & Yes & Yes & 1474 & Yes & 574 \\
\hline 10 & mataharimall.com & $\begin{array}{l}\text { bottom- } \\
\text { middle }\end{array}$ & No & No & Yes & 6279 & Yes & 580 \\
\hline
\end{tabular}

Table 2: Term of Use and Privacy Policies on Indonesia e-commerce

\section{Ease of access and availability.}

Terms and conditions are statements that regulate how a visitor uses a site. Consequently, the link to these documents should be prominently displayed. Although all the above mentioned websites have such links on the homepage, all the links are located at the bottom of the webpage. Two sites, such as elevenia and alfacart, do not have separate privacy policies. Instead the privacy policies are incorporated into the terms and conditions.

Six out of ten websites do not allow guest buyers (anonymous customers), and all these six require customers to agree to the terms and conditions by ticking a box during new customer registration. Although the remaining four websites allow one-time buying, bhinneka and lazada require customers to agree to the terms and conditions, whereas alfacart and shopee do not. Most consumers do not read any legal documents let alone lengthy ones (Subekti, 2014). Bhinneka.com has the shortest terms and conditions and privacy policy while lazada and shopee have the longest.

\section{Cookies and notifications.}

Three sites ask for the consumer's permission to allow notifications. This is a nice feature as they do not automatically use cookies without consent.

\section{Data Scoring}

We scored each of the five variables from 1 to 10 and then generated a combined score for each website. The highest score indicates the website that is most successfully geared toward privacy and yet does not confuse consumers with lengthy legal documents. The full score list is shown in Table 3. 
Table 3: Scoring of Indonesian Ecommerce Websites

\begin{tabular}{|c|c|c|c|c|c|c|c|c|c|c|c|c|}
\hline Site & $\begin{array}{l}\text { Sho } \\
\text { w } \\
\text { notif }\end{array}$ & $\mathrm{X} 1$ & $\begin{array}{l}\text { Gues } \\
\text { t buy }\end{array}$ & $\mathrm{X} 2$ & ToU & $\mathrm{X} 3$ & $\begin{array}{l}\text { ToU- } \\
\text { WC }\end{array}$ & $\mathrm{X} 4$ & PP & $\begin{array}{l}\mathrm{PP} \\
- \\
\mathrm{W} \\
\mathrm{C} \\
\end{array}$ & $\mathrm{X} 5$ & $\Sigma \mathrm{X}$ \\
\hline $\begin{array}{l}\text { tokopedia.co } \\
\mathrm{m}\end{array}$ & Yes & 10 & No & 5 & Yes & 10 & 5624 & 4.4 & Yes & $\begin{array}{l}14 \\
21\end{array}$ & 8.6 & 38 \\
\hline $\begin{array}{l}\text { bukalapak.co } \\
\mathrm{m}\end{array}$ & Yes & 10 & Yes & 10 & $\begin{array}{l}\text { Yes/ } \\
\text { But }\end{array}$ & 1 & 2981 & 7 & Yes & $\begin{array}{r}18 \\
2 \\
\end{array}$ & 9.8 & $\begin{array}{r}37 . \\
8 \\
\end{array}$ \\
\hline lazada.co.id & No & 5 & Yes & 10 & Yes & 10 & 9642 & 0.4 & Yes & $\begin{array}{l}19 \\
55\end{array}$ & 8 & $\begin{array}{r}33 . \\
4\end{array}$ \\
\hline $\begin{array}{l}\text { elevenia.co.i } \\
\text { d }\end{array}$ & No & 5 & No & 5 & Yes & 10 & 4879 & 5.1 & ToU & $\begin{array}{l}* * \\
* \\
\end{array}$ & 10 & $\begin{array}{r}35 . \\
1\end{array}$ \\
\hline blibli.com & No & 5 & No & 5 & Yes & 10 & 3204 & 6.8 & Yes & $\begin{array}{r}70 \\
4 \\
\end{array}$ & 9.3 & $\begin{array}{r}36 . \\
1 \\
\end{array}$ \\
\hline alfacart.com & No & 5 & No & 5 & Yes & 10 & 3614 & 6.4 & ToU & $\begin{array}{l}* * \\
* \\
\end{array}$ & 10 & $\begin{array}{r}36 . \\
4 \\
\end{array}$ \\
\hline blanja.com & No & 5 & No & 5 & Yes & 10 & 2838 & 7.2 & Yes & $\begin{array}{l}23 \\
09 \\
\end{array}$ & 7.7 & $\begin{array}{r}34 . \\
9 \\
\end{array}$ \\
\hline shopee.co.id & Yes & 10 & Yes & 10 & $\begin{array}{l}\text { Yes/ } \\
\text { But }\end{array}$ & 1 & 7811 & 2.2 & Yes & $\begin{array}{l}48 \\
76 \\
\end{array}$ & 5.1 & $\begin{array}{r}28 . \\
3 \\
\end{array}$ \\
\hline $\begin{array}{l}\text { bhinneka.co } \\
\mathrm{m}\end{array}$ & No & 5 & Yes & 10 & Yes & 10 & 1474 & 8.5 & Yes & $\begin{array}{r}57 \\
4 \\
\end{array}$ & 9.4 & $\begin{array}{r}42 . \\
9 \\
\end{array}$ \\
\hline $\begin{array}{l}\text { mataharimall. } \\
\text { com }\end{array}$ & No & 5 & No & 5 & Yes & 10 & 6279 & 3.7 & Yes & $\begin{array}{r}58 \\
0\end{array}$ & 9.4 & $\begin{array}{r}33 . \\
1\end{array}$ \\
\hline
\end{tabular}

quality levels of websites when searching for health information. Proceedings: A Conference of the American Medical Informatics Association/. AMIA Annual Fall Symposium. AMIA Fall Symposium, 774.

2. ConsumersUnion. (2016). Consumer Reports WebWatch Guidelines. Retrieved November 8, 2016, from http://consumersunion.org /news/consumer-reportswebwatch-guidelines/

3. Harsono, Hugh. (2016). Indonesia will be Asia's next biggest e-commerce market. Retrived August, 16, 2017.

4. Milne, George R., Rohm,

\section{CONCLUSION}

A simple analysis of Indonesian e-commerce websites indicated that bhinneka.com is the best ecommerce website in terms of privacy concerns. It allows guest buying in which the user does not have to store his or her data. Furthermore, it also takes precautions by forcing the user to accept their terms and conditions when buying from the website.

Bhinneka.com also has the shortest terms and conditions and privacy policy, thus enabling consumers to read them in only a few minutes. While lengthy legal documents may seem necessary, the use of common language enables consumers to understand these documents easily.

This paper introduces a simple framework for measuring the extent to which an e-commerce website successfully ensures that consumers agree and consent to its terms of use without burdening the consumer with lengthy and obscure legal documents.

\section{REFERENCES}

1. Adams, Samantha. (2003). Assessment strategies: how patients cope with the diverse
Andrew J., \& Bahl, Shalini. (2004). Consumers' protection of online privacy and identity. Journal of Consumer Affairs, 38(2), 217-232.

5. Subekti, Mohammad. (2014). Pengembangan Model E-Bisnis di Indonesia. ComTech: Computer, Mathematics and Engineering Applications, 5(2), 925-938.

6. Tsai, Janice Y., Egelman, Serge, Cranor, Lorrie, \& Acquisti, Alessandro. (2011). The effect of online privacy information on purchasing behavior: An experimental study. Information Systems Research, 22(2), 254-268.

7. A. M. McDonald and L. F. Cranor, "The Cost of Reading Privacy Policies," I/S: A Journal of Law and Policy for the Information Society, vol. 4, no. 3 , pp. $540-565,2008$

8. C. J. Hoofnagle, J. King, S. Li and J. Turow, "How Different are Young Adults From Older Adults When it Comes to Information Privacy Attitudes \& Policies?," University of Pennsylvania, 2010

9. M. A. Lemley, "Terms of Use,"Minnesota Law Review, vol. 91, pp. 459-483, 2006

10.E. Goldman, "How Zappos' User Agreement Failed In Court and Left Zappos Legally Naked,"Forbes.com, 10 October 2012 